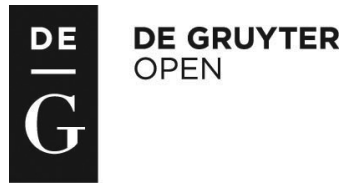

\title{
NUTRITIONAL VALUE OF YARROWIA LIPOLYTICA YEAST AND ITS EFFECT ON GROWTH PERFORMANCE INDICATORS IN PIGLETS*
}

\author{
Anna Czech ${ }^{1 \bullet}$, Aleksandra Smolczyk², Katarzyna Ognik ${ }^{1}$, Martyna Kiesz $^{1}$ \\ ${ }^{1}$ Department of Biochemistry and Toxicology, University of Life Sciences in Lublin, \\ Akademicka 13, 20-950 Lublin, Poland \\ ${ }^{2}$ Skotan S.A., Uniwersytecka 13, 40-007 Katowice, Poland \\ •Corresponding author: anna.czech@up.lublin.pl
}

\begin{abstract}
Yarrowia lipolytica yeast can be a valuable component of feed compounds due to its high content of protein and essential amino acids, as well as minerals. The objective of the study was to verify the research hypothesis that Yarrowia lipolytica $(\mathrm{YL})$ yeast, having a more valuable chemical composition than Saccharomyces cerevisiae (SC), can improve growth performance in piglets. An attempt was made to determine what proportion of YL yeast in a compound feed for piglets would produce measurable effects in terms of production and health. The experiment was carried out on 46-dayold piglets receiving experimental mixtures for 39 days. The piglets in the experimental groups were fed the same mixture as the control, but with $3 \%$ or $6 \%$ fodder yeast of the strain Yarrowia lipolytica A-101 in place of soybean meal. The YL fodder yeast had significantly higher content of alanine (by about $50 \%$ ), lysine, isoleucine and tryptophan (over 30\%), leucine, valine, glycine and glutamic acid (over $20 \%$ ), and tyrosine (by about $17 \%$ ) in comparison with SC yeast. Content of crude fat was three times higher than in SC yeast. YL yeast had significantly higher content of $\mathrm{Na}^{+}, \mathrm{K}^{+}, \mathrm{Ca}^{+2}, \mathrm{Mn}^{+2}, \mathrm{~S}, \mathrm{Mg}^{+2}$ and $\mathrm{Zn}^{+2}$ than $\mathrm{SC}$, as well as significantly higher content of vitamins $B_{2}$ and E. Yarrowia lipolytica fodder yeast introduced to compound feed in the amount of just $3 \%$ improved growth performance (an increase in daily weight gain and a decrease in feed conversion per $\mathrm{kg}$ weight gain). These results indicate that $\mathrm{YL}$ in the amount of $3 \%$ in compound feed can be successfully used in the diet of piglets in place of the commonly used SC.
\end{abstract}

Key words: Yarrowia lipolytica, yeast, piglets, performance

Yarrowia lipolytica (YL) has been used for many years in numerous branches of the food industry. It is involved in the ageing of products such as cheeses and sausages (Iucci et al., 2007) and is a valuable source of many enzymatic proteins, such as protease, esterase or lipase (Fickers et al., 2006; Kim et al., 2007). It can also produce large quantities of organic acids, such as citric, isocitric, pyruvic and alphaketoglutaric acid, as a source of carbon (Coelho et al., 2010; Zhou et al., 2010). Cur-

\footnotetext{
*Work financed from DS3.
} 
rently these microbes have also found wide application in production of protein-rich or lipid-rich biomass (Rymowicz et al., 1997). As a result of research on protein-rich biomass, on 20 September 2010 the FEFAC (European Feed Manufacturers' Federation) authorized Yarrowia lipolytica yeast, as a fodder material produced from the glycerine fraction derived from biofuel production, for marketing in the European Union. Its use in animal diets was intended not only to enrich feed compounds as a valuable source of protein, vitamins and minerals, but also to supply biomolecules with prebiotic or probiotic properties (Erasmus et al., 2005). In this regard research is being conducted on the use of Yarrowia lipolytica yeast in raising animal species such as turkeys (Czech et al., 2014; Merska et al., 2015) or fish (Hatlen et al., 2012; Berge et al., 2013). However, we have found no studies conducted on piglets.

Currently the most popular yeast on the market for use in animal feed is produced on a base of Saccharomyces cerevisiae and molasses. These preparations contain considerable quantities of crude protein (approx. 35.9-40.5\%), and the amino acid composition of yeast includes large amounts of glutamic acid, aspartic acid and lysine (Fadel et al., 2013). The nutritional value of yeast depends mainly on its chemical composition, which is influenced by such factors as production technology, the type of strains used and the quality of the medium serving as a source of substrates. For this reason the chemical composition of yeast of different strains may vary.

The objective of the study was to verify the research hypothesis that Yarrowia lipolytica (YL) yeast, having a more valuable chemical composition than Saccharomyces cerevisiae (SC), can improve growth performance in piglets. An attempt was made to determine what proportion of YL in a compound feed for piglets would produce measurable effects in terms of production and health.

\section{Material and methods}

The experiment was carried out on 264 piglets (165 barrows and 99 gilts), from litters of line 990 sows and boars, which were assigned to three experimental groups according to their body weight and age. The experimental group consisted of 88 piglets distributed in 11 pens ( 8 piglets per pen). The piglets in group K (control) received a base compound feed (Table 1) with no fodder yeast. The piglets in groups YL3 and YL6 received 3\% and 6\% fodder yeast of the strain Yarrowia lipolytica A-101 in their feed in place of soybean meal (group YL3 - $30 \mathrm{~kg}$ of yeast per tonne of feed; group YL6 - $60 \mathrm{~kg}$ of yeast per tonne of feed).

In view of the fact that no studies have been conducted on piglets using Yarrowia lipolytica yeast, the experiment was performed on somewhat older and stronger individuals. The average age of the piglets on the first day of the experiment was 46 days (the piglets were weaned from the sows in the third week after birth). The experiment lasted for 39 days.

The piglets in the experimental groups received complete mixed rations: Starter I (days 1 to 21 of the experiment) and then Starter II (days 22 to 39 of the experiment). The nutrient content in each period was in accordance with NRC (1998). Yarrowia 
lipolytica A-101 is a commercial product. It was produced on glycerol from rapeseed biofuel production.

The piglets were fed ad libitum, with permanent access to drinking water. Nutrient content in the feed mixtures was calculated (Table 1). Yeast in powder form was added to the feed mixtures during production of the mixtures.

Table 1. Composition of compound feed and nutrient content during each period of the experiment

\begin{tabular}{|c|c|c|c|c|c|c|}
\hline \multirow{3}{*}{ Item } & \multicolumn{6}{|c|}{ Experimental group } \\
\hline & \multicolumn{3}{|c|}{ days $1-21$ of experiment } & \multicolumn{3}{|c|}{ days $22-39$ of experiment } \\
\hline & $\mathrm{K}$ & YL3 & YL6 & $\mathrm{K}$ & YL3 & YL6 \\
\hline Barley meal & 42 & 42 & 42 & 35 & 35 & 35 \\
\hline Wheat meal & 35 & 35 & 35 & 35 & 35 & 35 \\
\hline Soybean protein concentrate & 6 & 6 & 6 & 0 & 0 & 0 \\
\hline Soybean meal & 9 & 6 & 3 & 20 & 17 & 14 \\
\hline YL yeast & 0 & 3 & 6 & 0 & 3 & 6 \\
\hline Wheat bran & 3.95 & 3.95 & 3.95 & 5.61 & 5.61 & 5.61 \\
\hline Soya oil ( $20 \%$ linolenic acid $)$ & 0.5 & 0.5 & 0.5 & 1 & 1 & 1 \\
\hline Premix $^{(1)}$ & 0.5 & 0.5 & 0.5 & 0.5 & 0.5 & 0.5 \\
\hline Calcium formate & 1.4 & 1.4 & 1.4 & 1.3 & 1.3 & 1.3 \\
\hline $\mathrm{MCP}-\mathrm{CaHPO}_{4}$ & 0.57 & 0.57 & 0.57 & 0.5 & 0.5 & 0.5 \\
\hline Salt & 0.4 & 0.4 & 0.4 & 0.4 & 0.4 & 0.4 \\
\hline DL-methionine & 0.03 & 0.03 & 0.03 & 0.04 & 0.04 & 0.04 \\
\hline Lysine $\mathrm{HCl}$ & 0.42 & 0.42 & 0.42 & 0.4 & 0.4 & 0.4 \\
\hline L-threonine & 0.12 & 0.12 & 0.12 & 0.14 & 0.14 & 0.14 \\
\hline Xylanase & 0.1 & 0.1 & 0.1 & 0.1 & 0.1 & 0.1 \\
\hline Phytase & 0.01 & 0.01 & 0.01 & 0.01 & 0.01 & 0.01 \\
\hline \multicolumn{7}{|l|}{ Nutrient content of the diets $(\%)$} \\
\hline Metabolizable energy (MJ) & 12.9 & 13.0 & 13.0 & 12.9 & 13.0 & 13.0 \\
\hline Crude protein $(\mathrm{g})$ & 181 & 180 & 180 & 181 & 180 & 180 \\
\hline Lysine $\mathrm{HCl} 98 \%$ (g) & 12.0 & 11.9 & 11.8 & 12.0 & 11.9 & 11.8 \\
\hline Methionine + Cystine $(\mathrm{g})$ & 6.40 & 6.40 & 6.40 & 6.40 & 6.40 & 6.40 \\
\hline Threonine (g) & 7.55 & 7.55 & 7.55 & 7.55 & 7.55 & 7.55 \\
\hline Calcium (g) & 7.04 & 7.04 & 7.04 & 7.04 & 7.04 & 7.04 \\
\hline Phosphorus (g) & 5.19 & 5.12 & 5.28 & 5.19 & 5.12 & 5.28 \\
\hline Sodium $(g)$ & 1.76 & 1.75 & 1.73 & 1.76 & 1.75 & 1.73 \\
\hline
\end{tabular}

(1) Vitamins and minerals (content in $1 \mathrm{~kg}$ ): vitamin $\mathrm{A}: 15,000 \mathrm{IU}$, vitamin $\mathrm{D}_{3}: 2,000 \mathrm{IU}$, vitamin $\mathrm{E}: 75 \mathrm{mg}$, vitamin $\mathrm{B}_{1}: 2.5 \mathrm{mg}$, vitamin $\mathrm{B}_{2}: 4 \mathrm{mg}$, vitamin $\mathrm{B}_{6}: 4 \mathrm{mg}$, vitamin $\mathrm{B}_{12}: 0.04 \mathrm{mg}$, vitamin PP: $30 \mathrm{mg}$, vitamin $\mathrm{K}_{3}$ : $2.5 \mathrm{mg}$, choline: $350 \mathrm{mg}$, Fe: $120 \mathrm{mg}$, Cu: $160 \mathrm{mg}$, Zn: $149 \mathrm{mg}$, Mn: $50 \mathrm{mg}$, I: $0.5 \mathrm{mg}$, Se: $0.30 \mathrm{mg}$, Co: $50 \mathrm{mg}$, folic acid: $1 \mathrm{mg}$, pantothenic acid: $14.00 \mathrm{mg}$.

\section{Chemical analysis of Yarrowia lipolytica and Saccharomyces cerevisiae yeast}

Samples of Yarrowia lipolytica and Saccharomyces cerevisiae yeast were collected for analysis in accordance with Commission Regulation (EC 152/2009) and Commission Regulation (EC 691/2013) amending Regulation (EC 152/2009) as regards methods of sampling and analysis. They were analysed for content of basic nutrients, i.e. crude protein, dry matter, crude ash, and crude fat, according to the AOAC 
procedure (2000). We also determined the quantitative composition of amino acids (by ion-exchange chromatography with spectrophotometric detection - IC-UV); content of vitamins, i.e. E (high-performance liquid chromatography with photodiode array detection - HPLC-DAD), $\mathrm{B}_{1}, \mathrm{~B}_{2}, \mathrm{~B}_{6}$ and $\mathrm{B}_{12}$ (high-performance liquid chromatography with fluorescence detection - HPLC-FLD); content of macro- and microelements, i.e. $\mathrm{Na}^{+}, \mathrm{K}^{+}, \mathrm{Mg}^{+2}, \mathrm{Ca}^{+2}, \mathrm{Fe}^{+2}, \mathrm{Mn}^{+2}, \mathrm{Zn}^{+2}, \mathrm{~S}$ (flame atomic absorption spectrometry - AAS) and phosphorus (by spectrophotometry); and content of heavy metals $\left(\mathrm{Cd}^{+2}\right.$ and $\mathrm{Pb}^{+2}$ by electrothermal atomic absorption spectrometry - ETAAS, $\mathrm{Hg}^{+2}$ by flame atomic absorption spectrometry - AAS, and $\mathrm{As}^{+3}$ by hydride generation atomic absorption spectrometry - HGAAS).

Microbiological analysis of the feed samples was performed as well (Salmonella; number of Clostridium perfringens per g; presence of coagulase-positive staphylococci in $25 \mathrm{~g}$ - horizontal methods; and the number of Enterobacteriaceae - plate method). Physical properties of the yeast were determined (organoleptic evaluation by the visual method and $\mathrm{pH}$ by the potentiometric method).

The yeast samples were also tested for the presence of mycotoxins. The contents of ochratoxin A, deoxynivalenol, and aflatoxin B1, B2, G1 and G2 were determined by high-performance liquid chromatography methods.

\section{Growth performance}

Growth performance in the piglets was evaluated on the basis of measurements of their body weight, feed consumption and conversion, as well as frequency of diarrhoea.

\section{Statistical analysis}

Statistical computations were carried out using Statistica v. 6.1.G software. The significance of differences between means was determined by one-way analysis of variance (ANOVA) at significance levels of 0.05 and 0.01 .

\section{Results}

The content of crude protein in the Yarrowia lipolytica yeast was slightly higher than in Saccharomyces cerevisiae yeast. It is particularly noteworthy that the content of crude fat in YL yeast was three times the content in $\mathrm{SC}(\mathrm{P} \leq 0.01)$. Content of crude ash in the two species was similar, at about $8 \%$ (Table 2).

The YL fodder yeast had significantly higher content of lysine (by about 30\%) than $\mathrm{SC}$ yeast $(\mathrm{P} \leq 0.01)$. YL also had significantly higher content of tryptophan (by about 34\%), tyrosine (by about 17\%), leucine (by about 26\%), isoleucine (by about $34 \%$ ), valine (by about 28\%), alanine (by about 50\%), glycine (by about 20\%) and glutamic acid (by about 22\%) than SC yeast. SC yeast had significantly higher content of arginine (by about 17\%) and proline (by about $41 \%$ ) than YL yeast. The content of sulphuric amino acids - methionine and cystine - was similar in the two species of yeast. 
Table 2. Content of nutrients (\%) and amino acids ( $\mathrm{g} \mathrm{kg}^{-1} \mathrm{D}$.W.) in fodder yeast

\begin{tabular}{|c|c|c|c|c|c|c|}
\hline \multirow{2}{*}{ Parameter } & \multicolumn{3}{|c|}{ Yarrowia lipolytica } & \multicolumn{3}{|c|}{ Saccharomyces cerevisiae } \\
\hline & $\min$. & $\max$ & mean & $\min$. & $\max$ & mean \\
\hline Crude protein & 39 & 48 & 43.50 & 31.14 & 48.98 & 40.06 \\
\hline Dry matter & 95 & 98 & 96.50 & 89.77 & 96.23 & 93.00 \\
\hline Crude ash & 7.79 & 8.33 & 8.01 & 7.39 & 8.61 & 8.00 \\
\hline Crude fat & 0.5 & 2.5 & $1.5 \mathrm{~A}$ & 0.45 & 0.55 & $0.50 \mathrm{~B}$ \\
\hline \multicolumn{7}{|c|}{ Amino acids } \\
\hline Aspartic acid & 25.39 & 46.21 & 35.80 & 30.02 & 38.88 & 34.45 \\
\hline Threonine & 10.22 & 29.98 & 20.10 & 15.85 & 18.77 & 17.31 \\
\hline Serine & 16.68 & 19.68 & 18.18 & 18.44 & 21.26 & 19.85 \\
\hline Glutamic acid & 49.81 & 71.56 & $60.68 \mathrm{a}$ & 45.87 & 53.35 & $49.61 \mathrm{~b}$ \\
\hline Proline & 14.70 & 19.62 & $17.16 \mathrm{~b}$ & 20.09 & 28.45 & $24.27 \mathrm{a}$ \\
\hline Glycine & 15.52 & 23.74 & $19.63 \mathrm{a}$ & 14.64 & 18.00 & $16.32 \mathrm{~b}$ \\
\hline Alanine & 32.63 & 40.05 & $36.34 \mathrm{~A}$ & 22.65 & 25.63 & $24.14 \mathrm{~B}$ \\
\hline Valine & 22.33 & 25.47 & $23.90 \mathrm{a}$ & 16.87 & 20.45 & $18.66 \mathrm{~b}$ \\
\hline Isoleucine & 18.67 & 21.07 & $19.87 \mathrm{a}$ & 12.63 & 17.05 & $14.84 \mathrm{~b}$ \\
\hline Leucine & 29.91 & 32.15 & $31.03 \mathrm{a}$ & 21.79 & 27.15 & $24.47 \mathrm{~b}$ \\
\hline Tyrosine & 13.52 & 16.42 & $14.97 \mathrm{a}$ & 11.09 & 14.53 & $12.81 \mathrm{~b}$ \\
\hline Phenylalanine & 15.44 & 18.98 & 15.44 & 12.49 & 19.05 & 15.77 \\
\hline Histidine & 8.93 & 10.23 & 9.58 & 8.01 & 10.29 & 9.15 \\
\hline Lysine & 27.27 & 38.41 & $32.84 \mathrm{~A}$ & 23.62 & 26.84 & $25.23 \mathrm{~B}$ \\
\hline Arginine & 12.31 & 23.89 & $18.10 \mathrm{~b}$ & 19.05 & 23.29 & $21.17 \mathrm{a}$ \\
\hline Cystine & 2.55 & 6.21 & 4.38 & 4.38 & 5.08 & 4.73 \\
\hline Methionine & 4.73 & 9.69 & 7.21 & 5.99 & 7.71 & 6.85 \\
\hline Tryptophan & 5.99 & 7.04 & $6.51 \mathrm{a}$ & 4.03 & 5.67 & $4.85 \mathrm{~b}$ \\
\hline
\end{tabular}

$\mathrm{a}, \mathrm{b}-$ average values with different letters differ significantly at $\mathrm{P} \leq 0.05$.

A, B - average values with different letters differ significantly at $\mathrm{P} \leq 0.01$.

YL has nearly twice the content of calcium and sodium and as much as 4 times the manganese content as SC yeast $(\mathrm{P} \leq 0.01)$. Content of sulphur, potassium, magnesium and zinc was also significantly higher in the YL yeast $(\mathrm{P} \leq 0.05)$ than in brewer's yeast. Only phosphorus content was significantly $(\mathrm{P} \leq 0.01)$ higher in $\mathrm{SC}$ yeast than in YL (Table 3$)$. YL yeast had significantly $(\mathrm{P} \leq 0.01)$ higher content of vitamin $\mathrm{B}_{2}$ (more than two-fold) and vitamin E (over 60\%), whereas SC yeast had significantly $(\mathrm{P} \leq 0.01)$ higher content of vitamin $\mathrm{B}_{1}$ (by about $21 \%$ ). Content of $\mathrm{B}_{6}$ in the two species was similar. In regard to the sensory properties analysed, the yeast had favourable properties of colour, odour, form, $\mathrm{pH}$ and density (Table 4). Microbiological analysis found no Salmonella, Clostridium perfringens or E. coli (Table 4).

The content of heavy metals in the yeast was low and did not exceed acceptable levels (Regulation of the Minister of Agriculture and Rural Development, 2012) (Table 5). The results of the mycotoxin tests were within acceptable norms (EC 576/2006) (Table 5).

Table 7 presents the frequency of occurrence of diarrhoea during the experiment in each of the experimental groups. In the animals from group YL6, receiving com- 
pound feed with $6 \%$ YL yeast, diarrhoea was observed more frequently and lasted longer (number of days with diarrhoea $=1.45 \%$; in the first days of the experiment 10 piglets had diarrhoea for 5 days). However, the diarrhoea had no significant effect on the growth of the animals. In comparison with the control (group K) and group YL6, daily weight gain was significantly higher in the piglets receiving feed containing 3\% YL fodder yeast, with lower feed conversion from days 22 to 39 of the experiment $(\mathrm{P} \geq 0.05)$ (Table 6).

Table 3. Content of minerals and vitamins in the dry weight of fodder yeast

\begin{tabular}{|c|c|c|c|c|c|c|}
\hline \multirow{2}{*}{ Parameter } & \multicolumn{3}{|c|}{ Yarrowia lipolytica } & \multicolumn{3}{|c|}{ Saccharomyces cerevisiae } \\
\hline & $\min$. & $\max$ & mean & $\min$. & $\max$ & mean \\
\hline Sodium $\left(\mathrm{g} \mathrm{kg}^{-1}\right)$ & 12.81 & 19.38 & $16.11 \mathrm{~A}$ & 7.87 & 8.93 & $8.40 \mathrm{~B}$ \\
\hline Potassium $\left(\mathrm{g} \mathrm{kg}^{-1}\right)$ & 19.10 & 25.14 & $22.12 \mathrm{a}$ & 16.41 & 18.27 & $17.34 \mathrm{~b}$ \\
\hline Sulphur $\left(\mathrm{g} \mathrm{kg}^{-1}\right)$ & 3.53 & 6.21 & $4.87 \mathrm{a}$ & 3.33 & 4.07 & $3.70 \mathrm{~b}$ \\
\hline Calcium $\left(\mathrm{g} \mathrm{kg}^{-1}\right)$ & 3.04 & 5.48 & $4.26 \mathrm{~A}$ & 1.99 & 2.47 & $2.24 \mathrm{~B}$ \\
\hline Phosphorus $\left(\mathrm{g} \mathrm{kg}^{-1}\right)$ & 3.40 & 5.28 & $4.34 \mathrm{~B}$ & 8.00 & 12.04 & $10.02 \mathrm{~A}$ \\
\hline Magnesium $\left(\mathrm{g} \mathrm{kg}^{-1}\right)$ & 1.82 & 2.04 & $1.93 \mathrm{a}$ & 1.30 & 1.66 & $1.48 \mathrm{~b}$ \\
\hline Manganese $\left(\mathrm{mg} \mathrm{kg}^{-1}\right)$ & 12.03 & 18.21 & $15.12 \mathrm{~A}$ & 3.35 & 4.33 & $3.84 \mathrm{~B}$ \\
\hline Zinc $\left(\mathrm{mg} \mathrm{kg}^{-1}\right)$ & 57.97 & 82.57 & $70.47 \mathrm{a}$ & 55 & 66.86 & $60.93 \mathrm{~b}$ \\
\hline Iron $\left(\mathrm{mg} \mathrm{kg}^{-1}\right)$ & 76.88 & 143.00 & 109.94 & 98.9 & 103.24 & 101.07 \\
\hline \multicolumn{7}{|l|}{ Vitamins (mg kg ${ }^{-1}$ D.W.) } \\
\hline Vitamin E & 6.04 & 7.52 & $6.78 \mathrm{~B}$ & 37.9 & 52.1 & $45.00 \mathrm{~A}$ \\
\hline Vitamin $\mathrm{B}_{1}$ & 80.76 & 115.24 & $98.00 \mathrm{~B}$ & 100.8 & 136.8 & $118.8 \mathrm{~A}$ \\
\hline Vitamin $\mathrm{B}_{2}$ & 11.01 & 21.47 & $16.24 \mathrm{~A}$ & 5.83 & 6.37 & $6.10 \mathrm{~B}$ \\
\hline Vitamin $\mathrm{B}_{6}$ & 25.43 & 31.41 & 28.42 & 19.3 & 33.7 & 26.50 \\
\hline Vitamin $B_{12}\left(\mu \mathrm{g} \mathrm{kg}^{-1}\right.$ d.m. $)$ & 52.80 & 60.00 & $56.40 \mathrm{~A}$ & 3.52 & 5.44 & $4.48 \mathrm{~B}$ \\
\hline
\end{tabular}

$\mathrm{a}, \mathrm{b}$ - average values with different letters differ significantly at $\mathrm{P} \leq 0.05$.

A, B - average values with different letters differ significantly at $\mathrm{P} \leq 0.01$.

Table 4. Organoleptic and microbiological evaluation of fodder yeast

\begin{tabular}{|c|c|c|c|c|c|c|}
\hline \multirow{2}{*}{ Parameter } & \multicolumn{3}{|c|}{ Yarrowia lipolytica } & \multicolumn{3}{|c|}{ Saccharomyces cerevisiae } \\
\hline & $\min$. & $\max$. & mean & $\min$. & $\max$. & mean \\
\hline Density $\left(\mathrm{kg} \mathrm{m}^{-3}\right)$ & 400 & 460 & 430 & 390 & 430 & 410 \\
\hline Specific weight $\left(\mathrm{N} \mathrm{m}^{-3}\right)$ & 3924 & 4415 & 4169.5 & 4001 & 4501 & 4251 \\
\hline $\mathrm{pH}$ & 3.8 & 6.0 & 4.9 & 4.0 & 6.1 & 5.01 \\
\hline Odour & yeast-like & & & yeast-like & & \\
\hline Colour & beige & & & pale yellow & & \\
\hline Form & powder & & & powder & & \\
\hline Salmonella (presence in $25 \mathrm{~g}$ ) & not detected & & & not detected & & \\
\hline $\begin{array}{l}\text { Clostridium perfringens (presence in } \\
0.1 \mathrm{~g} \text { ) }\end{array}$ & not detected & & & not detected & & \\
\hline E. coli (presence in $0.1 \mathrm{~g})$ & not detected & & & not detected & & \\
\hline
\end{tabular}


Table 5. Content of heavy metals $\left(\mathrm{mg} \mathrm{kg}^{-1}\right)$ and mycotoxins $\left(\mu \mathrm{g} \mathrm{kg}^{-1}\right)$ in fodder yeast

\begin{tabular}{l|c|c|c|c|c|c}
\hline \multirow{2}{*}{ Parameter } & \multicolumn{3}{c|}{ Yarrowia lipolytica } & \multicolumn{3}{c}{ Saccharomyces cerevisiae } \\
\cline { 2 - 7 } & min. & max. & mean & min. & max. & mean \\
\hline Arsenic & 0.025 & 0.36 & 0.29 & 0.022 & 0.034 & 0.028 \\
Cadmium & 0.028 & 0.050 & 0.039 & 0.034 & 0.039 & 0.037 \\
Mercury & 0.006 & 0.009 & 0.007 & 0.003 & 0.007 & 0.005 \\
Lead & 0.050 & 0.057 & 0.053 & 0.047 & 0.058 & 0.052 \\
Deoxynivalenol & 50.72 & 53.52 & 52.12 & 48.37 & 50.55 & 49.50 \\
Ochratoxin A & \multicolumn{7}{c}{ none } & & & none & none \\
Aflatoxin B1 & none & none & & none & none \\
Aflatoxin B2 & none & none & & none \\
Aflatoxin G1 & \multicolumn{7}{c}{ Aflatoxin G2 } & \multicolumn{3}{c}{} \\
\hline
\end{tabular}

Table 6. Growth performance results and cases of diarrhoea in piglets

\begin{tabular}{|c|c|c|c|}
\hline & \multicolumn{3}{|c|}{ Group } \\
\hline & $\mathrm{K}$ & YL3 & YL6 \\
\hline Age at start of experiment (days) & 46.75 & 45.71 & 45.62 \\
\hline \multicolumn{4}{|l|}{ Body weight $(\mathrm{kg})$ : } \\
\hline start of experiment & 10.78 & 11.15 & 11.04 \\
\hline 21 days of experiment & 19.10 & 19.98 & 19.61 \\
\hline 39 days of experiment & $30.19 \mathrm{~b}$ & $32.98 \mathrm{a}$ & $30.07 \mathrm{~b}$ \\
\hline \multicolumn{4}{|l|}{ Daily weight gain during period $(\mathrm{kg}), \mathrm{AGD}$} \\
\hline 1-21 days of experiment & 0.397 & 0.421 & 0.408 \\
\hline 22-39 days of experiment & $0.613 \mathrm{~b}$ & $0.722 \mathrm{a}$ & $0.581 \mathrm{~b}$ \\
\hline 1-39 days of experiment & $0.498 \mathrm{~b}$ & $0.560 \mathrm{a}$ & $0.489 \mathrm{~b}$ \\
\hline \multicolumn{4}{|l|}{ Mean daily feed intake (kg), ADFI } \\
\hline 1-21 days of experiment & 0.631 & 0.620 & 0.581 \\
\hline 22-39 days of experiment & 0.993 & 0.984 & 1.023 \\
\hline 1-39 days of experiment & 0.798 & 0.788 & 0.785 \\
\hline \multicolumn{4}{|l|}{ Feed conversion in $\mathrm{kg}$ per $\mathrm{kg}$ weight gain, FCR } \\
\hline 1-21 days of experiment & 1.59 & 1.47 & 1.42 \\
\hline 22-39 days of experiment & $1.62 \mathrm{~b}$ & $1.36 \mathrm{c}$ & $1.76 \mathrm{a}$ \\
\hline 1-39 days of experiment & $1.60 \mathrm{a}$ & $1.41 \mathrm{~b}$ & $1.61 \mathrm{a}$ \\
\hline Number of animals on the first day of the experiment & 88 & 88 & 88 \\
\hline Number of animals that died during the experiment & 2 & 3 & 2 \\
\hline Number of animals excluded from the experiment & 1 & 0 & 1 \\
\hline Number of days with diarrhoea & 1.00 & 0.82 & 1.45 \\
\hline
\end{tabular}

$\mathrm{a}, \mathrm{b}$ - values in the same rows with different letters differ significantly at $\mathrm{P} \leq 0.05$.

\section{Discussion}

The fodder market offers many kinds of fodder yeast, with substantially different chemical compositions. The results of our study show that in terms of chemical 
composition and nutritional value Yarrowia lipolytica yeast is not inferior to Saccharomyces cerevisiae, which is currently on the market. Differences in nutrient content may be due to factors such as production technology or the type of cultures or substrates used. It is particularly noteworthy that YL yeast has significantly higher content of lysine than SC yeast, which makes it a more valuable source of complete fodder protein. Because YL yeast is grown on glycerol, a by-product of production of biofuels from rapeseed (Rymowicz et al., 2010), it has substantially higher energy content than SC yeast. It should be noted that glycerol is a completely safe source of carbon and energy for YL yeast because it is registered as a feed additive (E 422) in the category 'technological additives' and there are no quantitative limits on its application in the animal species for which it is used (EC 1831/2003, 2008). According to a study by Rymowicz et al. (1997), Yarrowia lipolytica has the ability to accumulate large quantities of fat in its cells, in which over $90 \%$ of fatty acids are unsaturated, with a high percentage of essential fatty acids (28-44\%).

Fodder yeast and yeast-like preparations can act by a variety of mechanisms, such as modulation of the immune system (Davis et al., 2004), binding of pathogenic bacteria and their toxins (Mourāo et al., 2005), or interactions with the digestive tract (Mathew et al., 1998). By enhancing immune processes and thereby the health of animals, they indirectly contribute to improvement in growth performance. Positive effects of the use of fodder yeast in the diet of piglets have been presented by Shen et al. (2009). Using SC yeast the authors of the study obtained higher daily weight gain, which was reflected in greater feed intake. Van der Peet-Schwering et al. (2007) observed higher daily weight gain and better feed consumption per kg of weight gain in a group of piglets receiving SC yeast in their feed than in a control group. A study by van Heugten et al. (2003) also showed better growth performance following the use of live SC yeast cells. These results are consistent with the results of our study, as during the second period of the experiment (days 22-39) the piglets receiving feed containing 3\% YL yeast had a faster growth rate and lower feed conversion rate per $\mathrm{kg}$ of weight gain than the control and group YL6. Moreover, during the entire experiment the fewest cases of diarrhoea were noted in the group of piglets fed a mixture with $3 \%$ YL yeast. In the piglets fed a mixture containing $6 \%$ yeast, diarrhoea was observed more often and lasted longer. It is difficult to interpret the reduction in growth performance and the increase in the frequency of diarrhoea in the piglets receiving feed with 6\% Yarrowia lipolytica yeast. This may have been due to the body's adaptation to a larger dose of a supplement which not only contains basic nutrients but is also a rich source of numerous other bioactive substances. An excessive dosage of yeast could also cause uncontrolled fermentation processes in young piglets, which may have induced this type of response. The use of a smaller amount of fodder yeast is also more economical.

Yarrowia lipolytica yeast is a rich source of basic nutrients and has a high content of valuable amino acids (lysozyme, tryptophan, tyrosine, leucine, isoleucine, valine, alanine, glycine and glutamic acid), as well as minerals $\left(\mathrm{Ca}^{+2}, \mathrm{Zn}^{+2}, \mathrm{Na}^{+}, \mathrm{Mn}^{+2}, \mathrm{~S}, \mathrm{~K}^{+2}\right.$ and $\mathrm{Mg}^{+2}$ ), and can be successfully used in the amount of $3 \%$ of compound feed for piglets instead of the commonly used yeast Saccharomyces cerevisiae. 


\section{References}

AOAC (2000). Official Methods of Analysis of AOAC International, 17th Ed. AOAC, Gaithersburg, MD, USA.

B erg e G.M., H a t l e n B., O d o m J.M., Ru y te r B. (2013). Physical treatment of high EPA Yarrowia lipolytica biomass increases the availability of $n-3$ highly unsaturated fatty acids when fed to Atlantic salmon. Aquaculture Nutr., 19: 110-121.

Co e 1 h o M.A.Z., A m a r a l P.F.F., B e lo I. (2010). Yarrowia lipolytica: an industrial workhorse. Current Research, Technology and Education Topics in Applied Microbiology and Microbial Biotechnology, 2: 930-944.

Commission Recommendation (EC) No 576/2006 of 17 August 2006 on the presence of deoxynivalenol, zearalenone, ochratoxin A, T-2 and HT-2 and fumonisins in products intended for animal feeding. http://eur-lex.europa.eu/LexUriServ/LexUriServ.do?uri=OJ:L:2006:229:0007:0009:EN:pdf

Commission Regulation (EC) No 152/2009 of 27 January 2009 laying down the methods of sampling and analysis for the official control of feed. http://eur-lex.europa.eu/legal-content/EN/ TXT/?uri=celex:32009R0152

Commission Regulation (EU) No 691/2013 of 19 July 2013 amending Regulation (EC) No 152/2009 as regards methods of sampling and analysis. http://www.iss.it/binary/ogmm/cont/regolamento_691_2013_campionamento_mangimi.pdf

Community Register of Feed Additives pursuant to Regulation (EC) No 1831/2003, 38th edition: published on 22 December 2008.

Czech A., Merska M., Ognik K. (2014). Immunological and biochemical indicators of turkey hens blood after adding different doses of the yeast Yarrowia lipolytica to the feed mixtures. Ann. Anim. Sci., 14: 935-946.

Davis M.E., Brown D.C., Maxwell C.V., Johnson Z.B., Kegley E.B., Dvorak R.A. (2004). Effect of phosphorylated mannans and pharmacological additions of zinc oxide on growth and immunocompetence of weaning pigs. J. Anim. Sci., 82: 581-587.

Eras mus L.J., R ob in son P.H., Ah madi A., H inders R., Grrett J.E. (2005). Influence of prepartum and postpartum supplementation of a yeast culture and monensin, or both, on ruminal fermentation and performance of multiparous dairy cows. Anim. Feed Sci. Technol., 122: 219-239.

F a d e 1 M., K e e r a A.A., M o u a fi F.E., Kahil T. (2013). High level ethanol from sugar cane molasses by a new thermotolerant Saccharomyces cerevisiae strain in industrial scale. Biotechnol. Res. Int., Article ID 253286: 1-6.

F i c kers P., Ongen a M., D e st a in J., We e kers F., Th o n a r t P. (2006). Production and downstream processing of an extracellular lipase from the yeast Yarrowia lipolytica. FEMS Yeast Res., 5: 527-543.

Hatlen B., B erge G.M., Odom J.M., Mundheim H., Ruyter B. (2012). Growth performance, feed utilisation and fatty acid deposition in Atlantic salmon, Salmo salar L., fed graded levels of high-lipid/high-EPA Yarrowia lipolytica biomass. Aquaculture, 364-365: 39-47.

I uc ci L., Patrignani F., Belletti N., Ndagijimana M., Guerzoni M., Gardini F., L a n c i o t t i R. (2007). Role of surface-inoculated Debaryomyces hansenii and Yarrowia lipolytica strains in dried fermented sausage manufacture. Part 2: Evaluation of their effects on sensory quality and biogenic amine content. Meat Sci., 75: 669-675.

K i m J.T., K a ng S.G., W o o J.H., L e e J.H., J e ong B.C., K i m S.J. (2007). Screening and its potential application of lipolytic activity from a marine environment: characterization of a novel esterase from Yarrowia lipolytica CL180. Appl. Microbiol. Biotechnol., 74: 820-828.

Math ew A.G., Che t t in S.E., R o b b in s C.M., G old e n D.A. (1998). Effect of a direct-fed yeast culture on enteric microbial populations, fermentation acids, and performance of weanling pigs. J. Anim. Sci., 76: 2138-2145.

Merska M., Ognik K., Czech A. (2015). Antioxidant status and macro- and micronutrients in the blood plasma of turkey hens fed diets with varying content of the yeast Yarrowia lipolytica. Pol. J. Vet. Sci., 18: 709-714.

M ourāo J.L., P i nh e iro V., A 1 ve s A., Gu e d e s C.M., P in to L., S a a v e d ra M.J., S p ri ng P., K o c h e r A. (2005). Effect of mannan oligosaccharides on the performance, intestinal morphology and cecal fermentation of fattening rabbits. Anim. Feed Sci. Technol., 126: 107-120. 
National Research Council. Minerals. In: Nutrient Requirements of Swine. 10th ed. Washington, DC: National Academy Press; 1998: 156.

Regulation of the Minister of Agriculture and Rural Development of 6 February 2012 on the content of hazardous substances in feed (Journal of Laws of 2012, item 230).

Rymowicz W., Kinal S., Wojtatowicz M., Musiał I., B odarski R. (1997). The characteristic of yeast Yarrowia lipolytica biomass produced on the basis of fatty substrates (in Polish). Biotechnologia, 38: 71-77.

Rymowicz W., Fatykhova A.R., Kamzolova S.V., Rywińska A., Morogunov G. (2010). Citric acid production from glycerol-containing waste of biodiesel industry by Yarrowia lipolytica in batch, repeated batch, and cell recycle regimes. Appl. Microbiol. Biot., 87: 971-979.

Shen Y.B., Pi a o X.S., Kim S.W., Wang L., Li u P., Yoon I., Zhen Y.G. (2009). Effects of yeast culture supplementation on growth performance, intestinal health and immune response of nursery pigs. J. Anim. Sci., 87: 2614-2624.

van der Peet-Schwering C.M.C., Jansman A.J.M., Smidt H., Yoon I. (2007). Effects of yeast culture on performance, gut integrity, and blood cell composition of weaning pigs. J. Anim. Sci., 85: 3099-3109.

van Heugten E., Funderburke D.W., Dorton K.L. (2003). Growth performance, nutrient digestibility, and fecal microflora in weaning pigs fed live yeast. J. Anim. Sci., 81: 1004-1012.

Zhou J., Zhou H., Zhou Du G., Liming Li u L., Chen J. (2010). Screening of a thiamineauxotrophic yeast for $\alpha$-ketoglutaric acid overproduction. Lett. Appl. Microbiol., 51: 264-271.

Received: 23 II 2016

Accepted: 5 V 2016 